\title{
Schistosoma Mansoni: Partial Molecular Characterization of the Gene Encoding Zinc Finger Protein of the Lung Stage (7-Days Schistosomula)
}

\author{
Samir Mahgoub \\ Department of Biochemistry, Faculty of Medicine, Al-Minia University
}

\begin{abstract}
Schistosomiasis is a serious parasitic disease with world-wide distribution, causing an estimated 200000 deaths per year. Despite the fact that the global distribution of schistosomiasis has changed significantly in the past 50 years, particularly in regions where control strategies have been successfully employed, the disease remains endemic in over 70 developing countries and more than 200 million people are estimated to be harboring the disease. Chemotherapy, although effective, it does not prevent re-infection, and in addition, partial drug resistance may occur. Hence, immunological intervention in the form of a vaccine would contribute to the success of the present efforts. Most of the trials in the development of anti-schistosomiasis vaccine were involving membrane-associated antigens contained in the adult Schistosoma mansoni (S. mansoni) tegument because they are capable of stimulating protective immunity. In the current study, a trial to obtain antigen varieties which could be vaccine candidates by incorporating internal antigens of the lung stage of $\boldsymbol{S}$. mansoni (7-days schistosomula) in addition to the tegumental antigens was done. The soluble extract of the lung stage was obtained by sonicating the whole parasite, then, coupled to Sepharose-4B column for affinity purification of pooled sera collected from chronically infected patients. The purified sera were used to immunoscreen $\lambda \mathrm{gt} 11 \mathrm{cDNA}$ library of 7-days schistosomula. The plaques purification after three rounds of immunoscreening gave a number of cDNA clones. one of the isolated clones (clone 2-4) was amplified by PCR using $\lambda$ gt 11 forward and reverse primers, then, cloned in a plasmid vector $\left(\boldsymbol{P C R}^{T M} \mathbf{I I}\right)$. The cloned insert was partially sequenced $270 \mathrm{bp}$ from the 5'- end using Sp6 primer as well as $187 \mathrm{bp}$ from the 3'-end using $T 7$ primer. The sequenced part of the clone showed it has two open reading frames (ORFs) with 31-36\% homology to the gene that encodes Zinc Finger protein (the transcriptional regulatory protein) from a number of eukaryotic species including human, rat and mice.
\end{abstract}

\section{INTRODUCTION}

Schistosomiasis is a Neglected Tropical Disease that ranks with malaria and tuberculosis as a major source of morbidity affecting approximately 210 million people in
76 countries of the world, despite of strenuous control efforts ${ }^{l}$, the illness is a more serious problem than it was previously thought to be ${ }^{2}$.

In the last two decades great progress has been made in characterizing human responses to 
schistosomes $^{3}$ and testing different antigens of the parasite and different vaccination strategies ${ }^{4}$.

In recent years, considerable effort has been made to develop a protective vaccine against schistosome infection and several potential DNA constructs encoding several candidate molecules have been identified ${ }^{5,6,7,8,9}$ that could be useful for diagnosis, or may act as targets of protective immunity and/or chemotherapy ${ }^{10}$.

Transcription in eukaryotic cells is regulated by proteins that bind to specific regulatory sequences and modulate the activity of RNA polymerase $^{11}$.

Many different transcription factors have now been identified in eukaryotic cells, as DNA binding domains in eukaryotic transcription factors which exhibit a variety of structures. The most common structural motifs are the homeodomain, basic zipper (leucine zipper), helix-loop-helix and several types of zinc fingers ${ }^{12}$.

Zinc finger domains contain repeats of cysteine and histidine that bind central $\mathrm{Z}^{+2}$ ions and fold producing a compact domain from a relatively short length of the polypeptide chain. This structural motif is recognized in DNA- binding domains and also in proteins that do not bind to DNA. These domains were initially identified in the polymerase II factor TFIIIA but, are also common among transcription factors that regulate polymerase II promoters $^{12}$.

The first zinc finger structure is $\mathrm{C}_{2} \mathrm{H}_{2}$ zinc finger, containing three or more repeating finger units that bind as monomers; it is the most common DNA binding motifs in eukaryotic transcription factors ${ }^{13}$.The second type is $\mathrm{C}_{4}$ zinc finger, found in more than 100 transcription factors, contains only two finger units and binds to DNA as homodimers or heterodimers. $\mathrm{C}_{6}$ zinc finger is the third type, binds to DNA as homodimer in which the monomers associate through hydrophobic interactions along one face of their $\alpha$ helical regions ${ }^{14}$,

The molecular characterization of these regulatory proteins in Schistosoma may contribute to a better understanding of the biology of the parasite as well as the evaluation of these proteins as targets for immunotherapy or drug therapy ${ }^{15}$.

The main goal of the current study was the identification and molecular characterization of some unique antigens from the lung stage of S. mansoni and in the future studying their immunogenic potential as vaccine candidates for the protection against the parasite.

\section{MATERIALS \& METHODS}

Soluble extract of 7- days schistosomula. Cercariae were kindly offered by the Biochemistry laboratory of Theodore Bilharz Research Institute. Schistosomula were obtained by mechanical transformation of cercariae, then, separated from tails by centrifugation for $15 \mathrm{~min}$ over $70 \%$ percoll gradient at $2000 \mathrm{rpm}^{16}$. Schistosomula were recovered, washed three times, then, incubated in Modified MEM (Minimum Essential Medium containing $10 \%$ foetal calf protein) at 
$37^{\circ} \mathrm{C}$ in a humidified $5 \% \quad \mathrm{CO}_{2}$ incubator for 7 days. Finally, the living schistosomula were separated by centrifugation for $15 \mathrm{~min}$ at 2000 rpm over $60 \%$ percoll gradient ${ }^{17}$. The soluble extract was made by sonication of the parasites in a buffer containing $20 \mathrm{mM}$ Tris, $\mathrm{pH} 7.2$ and 2 mM phenyl methyl sulphonyl fluoride (PMSF), then, centrifuged at 6000 rpm for $20 \mathrm{~min}$. The supernatant was collected and stored at $-70^{\circ} \mathrm{C}$.

Affinity purification of sera. Sera used in the library immunoscreening were pooled from S. mansoni chronically infected patients admitted to Department of Tropical Medicine, Zagazig University Hospitals. Cyanogen bromide - activated Sepharose 4B was used to purify sera according to manufacturer's instructions by coupling 6-8 $\mathrm{mg}$ of 7- days' schistosomula soluble extract to the column. Pooled sera were precipitated with $45 \%\left(\mathrm{NH}_{4}\right)_{2} \mathrm{SO}_{4}$, the precipitate was redissolved in phosphate buffered saline (PBS) $(0.4 \mathrm{~g} \mathrm{NaCl}, \quad 1.44 \mathrm{~g}$ $\mathrm{Na}_{2} \mathrm{HPO}_{4}$ and $0.24 \mathrm{~g} \mathrm{KH}_{2} \mathrm{PO}_{4} /$ liter) and dialyzed against PBS overnight $(\mathrm{O} / \mathrm{N})$. The dialysate was, then, passed onto the column coupled to which schistosomula soluble extract. The column was washed with $30 \mathrm{ml}$ PBS. Antibodies bound to the column were eluted by $0.1 \mathrm{M}$ glycine- $\mathrm{HCl}$, $\mathrm{pH} 2.6$ and collected as $1 \mathrm{ml}$ fractions. The $\mathrm{pH}$ of the elute was immediately adjusted to 7.0 with $100 \mu 11 \mathrm{M}$ Trisbase., then, it was dialyzed against PBS over night to be ready for immunoscreening.

Immunoscreening of schistosomula $\lambda$ gt $11 \quad$ cDNA library $^{18}$. To grow cells for transfection with the library, a single colony of E.Coli Y1090 was incubated in $50 \mathrm{ml}$ LB-ampicilline medium (LB-amp) (10 g Bactotryptone, $5 \mathrm{~g}$ Bacto-yeast extract, $10 \mathrm{~g}$ $\mathrm{NaCl}$, and distilled $\mathrm{H}_{2} \mathrm{O}$ up to 1 liter, pH 7.0) containing $0.2 \%$ maltose and ampicilline $100 \mathrm{mg} / \mathrm{ml}$ allowed to grow overnight at $37^{\circ} \mathrm{C}$, to be used as hosts for plating the library. For the primary screening of the library, 150 mm LB-amp plates were used and 90 $\mathrm{mm}$ plates were used for secondary and tertiary screenings. $0.6 \mathrm{ml} /$ large plate and $0.2 \mathrm{ml} / \mathrm{small}$ one of the overnight bacterial culture was incubated with $0.1 \mathrm{ml}$ of SM medium (5.8 g NaCl, $2.0 \mathrm{~g} \mathrm{MgSO}_{4} .7 \mathrm{H}_{2} \mathrm{O}, 50$ $\mathrm{ml} 1 \mathrm{M}$ Tris ; $\mathrm{pH} 7.5$ and $5 \mathrm{ml}$ of $2 \%$ gelatin solution/ liter). The cell suspension was incubated at $37^{\circ} \mathrm{C}$ for 15 min to allow the adsorption of the phage to the bacterial cells. $7 \mathrm{ml} /$ large plate and $3.5 \mathrm{ml} / \mathrm{small}$ plate of the molten top agar was cooled to $50^{\circ} \mathrm{C}$ and added to the infected cells, then, poured onto the LB-amp plates prewarmed to $37^{\circ} \mathrm{C}$. The plates were incubated at $40^{\circ} \mathrm{C}$ for 3-4 hours (hrs). Dry nitrocellulose $(132 \mathrm{~mm}$ and 82 $\mathrm{mm}$ ) circular filters were used for large and small plates, respectively. The filters were saturated in $10 \mathrm{mM}$ IPTG and air dried, then, placed onto the plates. The plates were transferred to a $37^{\circ} \mathrm{C}$ incubator for another $3 \mathrm{hrs}$. then, the filters were removed from the plates and transferred to the Blotto buffer [5g non fat dry milk $/ 100 \mathrm{ml}$ TBST $(37.5 \mathrm{ml} 4 \mathrm{M} \mathrm{NaCl}, 10 \mathrm{ml} 1 \mathrm{M}$ Tris; $\mathrm{pH} 8.0$, double distilled $\mathrm{H}_{2} \mathrm{O}$ up to 1 liter and $0.05 \%$ Tween-20 )] to block the non-specific binding protein sites. The filters were, then, washed 3 times in TBST for $10 \mathrm{~min}$ each, 
followed by incubation for $3 \mathrm{hrs}$ with the purified sera over schistosomula soluble extract column (primary antibody), then, washed 4 times at room temperature (RT) in TBST for $20 \mathrm{~min}$ each. The anti-rabbit $\mathrm{IgG}$ alkaline phosphatase conjugate (secondary antibody) diluted in TBST was incubated with the primary antibody-antigen complex for $1 \mathrm{hr}$ at RT. Then, the filters were washed 4 times in TBST for $10 \mathrm{~min}$ each, dried and transferred to the color development substrate solution [33 $\mu$ l of $50 \mathrm{mg} / \mathrm{ml}$ Nitro Blue Tetrazolium $(\mathrm{NBT})+16.5 \mu \mathrm{l}$ of $50 \mathrm{mg} / \mathrm{ml} \mathrm{BCIP}$ per ml AP buffer (10 $\mathrm{ml}$ of $1 \mathrm{M}$ Tris; $\mathrm{pH} 9.5,2 \mathrm{ml}$ of $5 \mathrm{M} \mathrm{NaCl} 0.5 \mathrm{ml}$ of 1 $\mathrm{M} \mathrm{MgCl}$, distilled $\mathrm{H}_{2} \mathrm{O}$ up to 100 $\mathrm{ml})$. The filters were incubated in dark until the desired color intensity had been developed, then, rinsed in distilled water. The developed filters were used to pick up agar plugs containing phage particles corresponding to the signals on the filters (the positive plaques) to be suspended into $0.5 \mathrm{ml}$ of SM medium. The purified phage plaques were used for the next round of screening.

Small scale preparation of bacteriophage DNA $^{19}$. A bacteriophage suspension in E.Coli Y1090 culture ( $\mathrm{O} / \mathrm{N}$ ) culture, incubated at $37^{\circ} \mathrm{C}$ for $15 \mathrm{~min}$, then, to which $4 \mathrm{ml}$ of NZCY-ampicilline medium ( $10 \mathrm{~g}$ NZ amine, 5 g Bactoyeast extract, $5 \mathrm{~g} \mathrm{NaCl}, 2 \mathrm{~g} \mathrm{MgSo}_{4} .7$ $\mathrm{H}_{2} \mathrm{O}$ and distilled $\mathrm{H}_{2} \mathrm{O}$ up to 1 liter ,then , autoclaved at $121^{\circ} \mathrm{C}$ and ampicilline was added $100 \mathrm{mg} / \mathrm{ml}$ ). The culture was agitated at $37^{\circ} \mathrm{C}$ for 9 hours (hrs), followed by adding $0.1 \mathrm{ml}$ chloroform. The lysate was, then, centrifuged at $8000 \mathrm{rpm}$ for $10 \mathrm{~min}$.
Ribonuclease A and DNase I (Sigma) were added to supernatant to final concentration $1 \mu \mathrm{g} / \mathrm{ml}$ of each. An equal volume of ice cold solution containing 20\% PEG-8000 and $2 \mathrm{M}$ $\mathrm{NaCl}$ in $\mathrm{SM}$ medium were added to lysate and chilled on ice for $1 \mathrm{hr}$, followed by centrifugation at 10000 rpm at $4^{\circ} \mathrm{C}$ to pellet the phage particles which were suspended in 0.5 $\mathrm{ml} \mathrm{SM}$ medium. To the suspension 5 $\mu \mathrm{l}$ of each $10 \%$ SDS and $0.5 \mathrm{M}$ EDTA, $\mathrm{pH} 8$ were added and incubated at $68^{\circ} \mathrm{C}$ for $15 \mathrm{~min}$. The solution was, then, extracted with phenol, phenol-chiasm and chiasm respectively, each extraction was done once, then, precipitated by adding $1 / 10$ volume of $3 \mathrm{M}$ Sodium acetate and 2.5 volume of ice-cold absolute ethanol and stored at $-20^{\circ} \mathrm{C} \mathrm{O} / \mathrm{N}$, then, dissolved in $100 \mu \mathrm{l}$ distilled $\mathrm{H}_{2} \mathrm{O}$ ,then, checked by using $0.7 \%$ agarose gel electrophoresis.

Polymerase Chain Reaction $(\mathbf{P C R})^{20}$. The isolated phage DNA from plaques was amplified using a pair of primers, $\lambda \mathbf{g t} 11$ forward (5'GGTGGCCACGACTCCTGGAGGCGG$\left.3^{\prime}\right)$ and $\lambda$ gt 11 reverse (5'-TTGACA CCAGACCAACTGGTAATC- $\left.3^{\prime}\right)$. A typical PCR reaction was done $(10 \mu \mathrm{l}$ $10 \mathrm{X}$ Taq DNA polymerase buffer, 16 $\mu \mathrm{l}$ of $1.25 \mathrm{mM}$ dNTP, $5 \mu \mathrm{l}$ forward primer, $5 \mu 1$ reverse primer, $2 \mu l(100$ ng) phage DNA template, $0.5 \mu \mathrm{l} \mathrm{Taq}$ DNA polymerase (Perkin-Elmer Cetus and Stratagene), sterile distilled $\mathrm{H}_{2} \mathrm{O}$ up to $\left.100 \mu \mathrm{l}\right)$.The reaction components were mixed in a microfuge and a drop of mineral oil was added. In the thermal cycler (Gene Amp 9600, Perkin-Elmer), a 3file program was used to amplify samples, where they were denatured 
in the first file at $94^{\circ} \mathrm{C}$ for $1 \mathrm{~min}$, then, the primers were annealed to the denatured templates at $55^{\circ} \mathrm{C}$ for $2 \mathrm{~min}$ and finally extended at $72^{\circ} \mathrm{C}$ for 10 $\min$. The amplicons were withdrawn from underneath the oil and $10 \mu \mathrm{l}$ aliquots were separated on $1 \%$ agarose gel.

Subcloning of the recombinant gene in $\mathbf{P C R}^{\mathrm{TM}}$ II vector ${ }^{19}$. The original TA cloning Kit (Invitrogen) was used for direct insertion of the amplicon into $\mathbf{P C R}{ }^{\mathbf{T M}} \mathbf{I I}$ vector at EcoR1 site. A ligation reaction was prepared $(1 \mu \mathrm{l}$ PCR product, $1 \mu \mathrm{l}$ of $10 \mathrm{X}$ ligation buffer, $2 \mu \mathrm{l}$ plasmid vector, sterile $\mathrm{H}_{2} \mathrm{O}$ up to $9 \mu \mathrm{l}, 1 \mu \mathrm{l}$ DNA ligase), then, incubated $\mathrm{O} / \mathrm{N}$ at $15^{\circ} \mathrm{C}$ till ready for transformation. The vial containing the ligation reaction was placed on ice. Two $\mu 1$ of $0.5 \mathrm{M} \beta$ mercaptoethanol and $2 \mu \mathrm{l}$ of ligation reaction were added to each vial of the INV competent cells and mixed gently, then, the vial was incubated on ice for $30 \mathrm{~min}$ followed by $30 \mathrm{sec}$ in $42^{\circ} \mathrm{C}$ water bath, then, on ice for 2 min, finally shaked at $37^{\circ} \mathrm{C}$ for $1 \mathrm{hr}$ with $450 \mu \mathrm{l}$ of SOC medium. An aliquot of $50 \mu \mathrm{l}$ was spread onto LBamp plate and the plate was placed inverted at $37^{\circ} \mathrm{C}$ for at least $18 \mathrm{hrs}$. Positive transformants can be selected by using Cracking gel procedure ${ }^{21}$, then, checked by $1 \%$ agarose gel electrophoresis.

Small scale preparation of plasmid $\mathbf{D N A}^{22}$. A single bacterial colony that contains the desired plasmid was used to inoculate $100 \mathrm{ml}$ of LB-amp medium incubated at $37^{\circ} \mathrm{C}$ with vigorous $\mathrm{O} / \mathrm{N}$ shaking. The bacterial cells were centrifuged at $10000 \mathrm{rpm}$ for $10 \mathrm{~min}$. For cells lysis solution I was used $(50 \mathrm{mM}$ glucose,
$25 \mathrm{mM}$ Tris $\mathrm{HCl}, \mathrm{pH} 8,10 \mathrm{mM}$ EDTA, $\mathrm{pH}$ 8) and freshly prepared lysozyme was added, then, followed by solution II $[0.2 \mathrm{M} \mathrm{NaOH}, 1 \%$ sodium dodecyl sulphate (SDS)], the suspension was incubated at RT for $10 \mathrm{~min}$ followed by adding $20 \mathrm{ml}$ of solution III ( $3 \mathrm{M}$ potassium acetate, 2 $\mathrm{M}$ glacial acetic acid). DNA was recovered by adding an equal volume of isopropanol and precipitated by centrifugation at $10000 \mathrm{rpm}$ for 10 min at RT. The pelleted DNA was dissolved in $100 \mu \mathrm{l}$ distilled $\mathrm{H}_{2} \mathrm{O}$ to which RNase $(10 \mathrm{mg} / \mathrm{ml})$ was added, then, left at $37^{\circ} \mathrm{C}$ for $2 \mathrm{hrs}$. The DNA solution was, extracted with phenolchiasm, then, precipitated by ethanol 2.5 volumes and 0.1 volume of $3 \mathrm{M}$ sodium acetate. DNA pellet was dissolved in $50 \mu \mathrm{l}$ distilled $\mathrm{H}_{2} \mathrm{O}$. O.D $_{260}$ was used to quantitate the DNA, then, stored at $-20^{\circ} \mathrm{C}$.

DNA sequencing ${ }^{23} .5 \mu 1$ of the plasmid DNA were denatured by 20 $\mu \mathrm{l}$ of $0.2 \mathrm{M} \mathrm{NaOH}$ for $5 \mathrm{~min}$, neutralized by $8 \mu \mathrm{l}$ of $5 \mathrm{M}$ ammonium acetate $\mathrm{pH} 7.4$, incubated at $-70^{\circ} \mathrm{C}$ for 30 min after precipitation with $100 \mu l$ ice-cold absolute ethanol. The DNA was pelleted and dried, then, dissolved in $4 \mu \mathrm{l}$ distilled $\mathrm{H}_{2} \mathrm{O}, 2 \mu \mathrm{l}$ of $5 \mathrm{X}$ sequanase reaction buffer, $2 \mu \mathrm{l}$ of the primer ( $\mathrm{Sp} 6$ and $\mathrm{T} 7$ for sequencing from $5^{/-}$end and $3 /$-end, respectively) were added to the denatured template, this mixture was boiled, then, cooled gradually to RT. $1 \mu \mathrm{l}$ of $0.1 \mathrm{M}$ DTT, $1 \mu 1 \boldsymbol{\alpha}^{\mathbf{3 5}} \mathbf{S}-\mathbf{d A T P}$ and $2 \mu \mathrm{l}$ 1:4 diluted sequanase enzyme were added to the reaction mix and the tube was incubated at RT for $5 \mathrm{~min}$. $3.5 \mu \mathrm{l}$ aliquots were added to 4 different tubes each containing 2.5 $\mu \mathrm{l}$ of each of the ddNTPs 
termination mixes. The reaction was stopped by adding $4 \mu \mathrm{l}$ stop dye. The 4-tube set were labeled G,A,T,C was heated for $5 \mathrm{~min}$, then, chilled on ice and loaded onto sequencing gel $(8 \%$ Polyacrylamide, $8 \mathrm{M}$ urea gel ), the run was continued for 2.5 and $6.5 \mathrm{hrs}$. After electrophoresis, the gel was fixed in a solution of $10 \%$ acetic acid and $10 \%$ methanol for $30 \mathrm{~min}$, dried and exposed to an X-ray film. After $24 \mathrm{hrs}$ exposure, the film was developed and read from the bottom. The informations obtained from DNA sequence were analyzed using the Genetics Computer Group Sequence analysis Software package.

\section{RESULTS}

Sera obtained from S. mansoni chronically infected patients were purified over an antigen column made from soluble extract of 7-days schistosomula coupled to Sepharose4B beads. The affinity purified eluted antibodies were, then, used to immunoscreen 7-days schistosomula $\lambda$ gt11 cDNA library. After the three rounds of immunoscreening. Phage DNA was prepared and checked using $0.7 \%$ agarose gel (Fig. 2), then, cloned into $\mathrm{PCR}^{\mathrm{TM}} \mathrm{II}$ vector. Some of the isolated clones were checked for size after being inserted into the vector using two restriction enzymes EcoR1 and BamH1 (Fig. 3), which showed no BamH1 site in the inserts, while, the enzymatic digestion of plasmid DNA by EcoR1 gave the actual size of each insert (Fig. 3). The partial DNA sequence (270 bp from 5'-end using Sp6 and 187 bp from 3'end using T7) (Fig. 4) of the insert showed that it has two open reading frames (ORFs) of 90 amino acids. It has 31-36\% homology with zinc finger protein from a number of eukaryotic species (including rat, mice and human). Fig. 1 shows the nucleotides and amino acids sequence.

Sp6: gct atg att caa get tgg tac cga gct cgg atc gca cta gta acg gcc gcc agt gtg ctg gaa ttc ggc ttg gtg ggc agg act cet gga gec cgt cag tat cgg cgg at tcc tca cac caa cag tge gge gtc gta agc aa caa tic acc cat acc cac caa aa gga agg cac ctt cgg tta aac aga ccc tgg agt tt cca gta tgc cca ggt aca aat cac atc tca tca gcc gtg aat tcc cag agt ctt tca gtt caa tct

A Met I A W YR ARI A L V T A S V L F GL V GR T P A R Q Y R N S H Q C G V VSKQFTHTHQKGRHLRLNRP WSFP VCPGTNHISSA VNSQSLSVQS

T7: gcc gcc agt gtg atg gat atc tgc aga att ccg gct ttt cgc acc aga cca act ggt aat ggt agc gac cag ttt cag ctg gaa ttc cag cgg agg aa aga a ac gta aca agg att ccc cta gta act gcg agt gaa cag gga tta gcc caa ctc cga agc ctg cgt tat ttg atc gta agg caa $t$

Fig. 1: The partial nucleotides and deduced amino acids sequences of the gene encoding zinc finger protein isolated from $\lambda$ gt 11 cDNA library of 7-days schistosomula. 


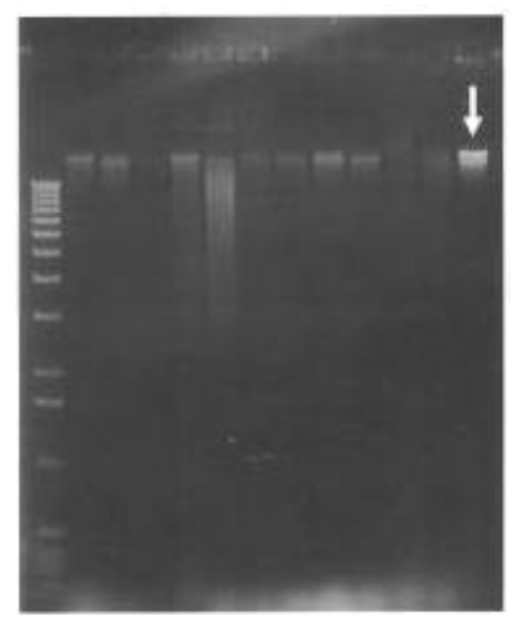

Fig. 2: $0.7 \%$ agarose gel representing the preparation of phage DNA isolated from $\lambda$ gt 11 cDNA library of the lung stage, the arrow points at the selected clone.

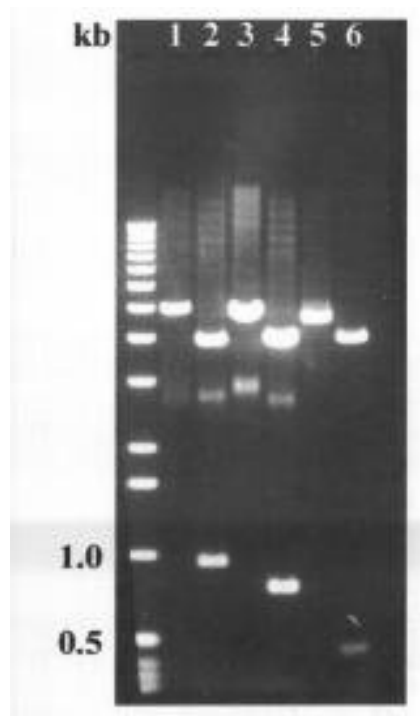

Fig. 3: 1\% agarose gel showing the digestion pattern of three isolated clones from $\lambda$ gt11 cDNA library of 7-day schistosomula cloned in $\mathbf{P C R}^{\mathbf{T M}} \mathbf{I I}$ vector, using two restriction enzymes $\boldsymbol{E} \boldsymbol{c o R} \boldsymbol{I}$ and $\boldsymbol{B} \boldsymbol{a m} \boldsymbol{H} \mathbf{1}$, the plasmid DNA samples were arranged in double, each represents from left to right, $\boldsymbol{B a m H 1}$ digested and $\boldsymbol{E c o R} \mathbf{l}$ digested DNA. The selected clone (2-4) was run in lanes 5 and 6 , its size is $0.4 \mathrm{~kb}$ and the $1 \mathrm{~kb}$ ladder is indicated on the left side of the gel. 


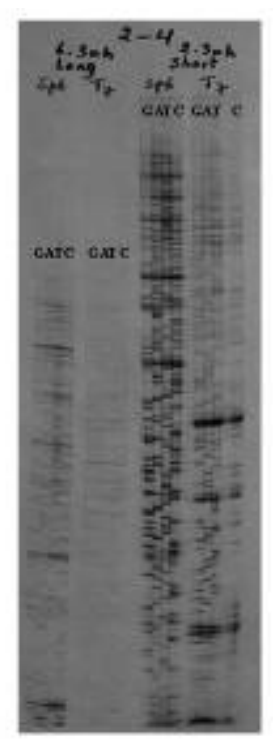

Fig. 4: An autoradiogram showing the partial sequence of the gene encoding zinc finger protein of $\boldsymbol{S}$. mansoni isolated from $\lambda \mathbf{g t} 11 \mathrm{cDNA}$ library of 7-days schistosomula.

\section{DISCUSSION}

A useful approach to fight $S$. mansoni should include the infrastructure, the educational components, as well as the development of vaccines and new drugs $^{24}$, as recommended by $\boldsymbol{W H O}^{25}$.

Current advances in postgenomic techniques are providing new avenues to identify the secreted and surface exposed antigens that mediate protection ${ }^{26,27,28}$.

The sequencing of the $\boldsymbol{S}$. mansoni transcriptome and genome has opened up exciting new possibilities for antigen discovery ${ }^{29}$.

As stated in the recent and high quality review on schistosome genomics by ${ }^{30}$, some potential drug targets should include proteins involved in DNA replication, transcription and repair systems of the parasite.

During its development, the parasite $\boldsymbol{S}$. mansoni is exposed to different environments and undergoes many morphological and physiological transformations as a result of profound changes in gene expression and characterization of proteins involved in the regulation of these processes.

S. mansoni transcriptome project showed that $2.4 \%$ of the categorized Expressed Sequence Tags under the Molecular Function in Gene Ontology encode transcriptional regulators. A search for conserved domains using the Pfam database in a subset of those transcripts showed that $5 \%$ of them consist of zinc fingers of the $\mathrm{C}_{2} \mathrm{H}_{2}$ group $^{29}$. These findings reinforce the importance of this class of regulatory proteins for $\boldsymbol{S}$. mansoni biology.

In addition, using the SAGE approach, ${ }^{31}$ found that $9.7 \%$ of the most abundant genes (genes containing more than 500 tags) from S. mansoni adult worms comprise those from the nucleic acid binding functional categories.

Proteins containing zinc finger motifs usually participate in regulatory processes and are considered the major class of transcription factors in eukaryotes ${ }^{32}$ more over they are considered the most popular DNA binding proteins in mammals ${ }^{33}$, involved in proteinDNA interactions and in the binding of RNA, lipids and proteins ${ }^{34}$. 
SmZF1, a S. mansoni zinc finger $(\boldsymbol{Z} \boldsymbol{F})$ protein, $19 \mathrm{kDa}$ containing three $\mathrm{C}_{2} \mathrm{H}_{2}$ type zinc finger motifs, binds both DNA and RNA oligonucleotides, with a higher affinity to DNA molecules. A single zinc-finger domain by itself is not sufficient for high-affinity binding to a specific DNA target sequence ${ }^{35}$.

This suggests that this protein might act as a transcription factor in the parasite and was detected in the nucleus of adult male worms $\lambda$ gt11 expression library and by PCR amplification in egg, cercariae and schistosomula cells cDNA libraries, but was not observed in female cells, suggesting it to be gender specific ${ }^{32}$.

According to ${ }^{36}$, investigating proteins differentially associated with each sex, they could reveal important clues concerning the formation of sexually mature schistosomes led to the description of novel chemotherapeutic targets acting in the maturation process, more over the protein is essential for the metabolism during different stages of the parasite life cycle ${ }^{37}$.

In the present study, the gene encoding zinc finger protein of 7-days schistosomula was identified by its isolation from cDNA library of the lung stage of $\boldsymbol{S}$. mansoni using sera obtained from the chronically infected patients, after purification over Sepharose-4B column made from sonicated soluble extract of 7-days schistosomula. The whole lung stage sonication was done to increase the chances for the isolation of a great number of $\boldsymbol{S}$. mansoni vaccine candidates; in fact what was obtained in this study is not a surface associated protein.
Recently, there has been a great deal of progress in the development of modular protein domains that recognize specific DNA triplets. The $\mathrm{C}_{2} \mathrm{H}_{2}$ zinc finger motif is the ideal structural scaffold on which a sequence specific protein may be constructed $^{38}$. DNA structural domain of zinc finger proteins usually consists of 3 or 6 zinc fingers. Artificial zinc finger proteins technology allows DNA sequences to be selected directionally and a DNA binding domain to be constructed ${ }^{39}$.

Various screening procedure and artificial design strategies have also been attempted to make zinc finger proteins to bind to desired sequences $^{40,41}$. Such artificial zinc finger proteins are expected to be artificial transcriptional factors and nucleases ${ }^{42}$

\section{ACKNOWLEDGEMENT}

Thanks for every member in the biochemistry laboratory in Theodore Bilharz Research Institute especially Prof. Mohamad Ali Saber for providing all materials used in the research and their technical assistance.

\section{REFERENCES}

1. Berriman, M., Brian, J. H., Philip. T. L., Alan, W. R., Gary, P. D., Gustavo, C. C., Susan, T. M., Al-Lazikani, B., Luiza, F. A., Peter, D. A., Martin, A. A., Daniella, C. B., Gaelle, B., Conor, R. C., Avril, C., Richard, C., Tim, A. D., Art, Delcher, ${ }^{6}$ Ricardo DeMarco, ${ }^{4,15,16}$ Apolliniare Djikeng, ${ }^{2}$ Tina Eyre, ${ }^{1}$ John A. G., Elodie, G., Yong, G., 
Christiane, H., Hirohisha, H., Yuriko, H., Robin, H., Alasdair, I., David, A. J., Daniela, L., Camila, D. M., Paul, M., Zemin, N., Guilherme, O., John, P. O., Julian, P., Mihaela, P., Raymond, J. P., Anna. V. P., Michael, A. Q., Marie-Adèle, R., Jane, R., Mohammed, S., Steven, L. S., Mario, S., Adrian, R. T., Owen, W., David, L. W., Jennifer, W., Wenjie, W., Mostafa, Z., Adhemar, Z., Claire, M. F., Barclay, G. B., and Najib M. E.(2010): The genome of the blood fluke Schistosoma mansoni. Nature 16; 460(7253): 352-358.

2. Finkelstein, J.L., Schleinitz, M.D., Carabin, H. and McGarvey, S.T. (2008): Decision-model estimation of the age-specific disability weight for schistosomiasis japonica: a systematic review of the literature. PLoS Negl. Trop. Dis., 2:e158

3. Dunne, D.W. and Mountford, A.P. (2001): Resistance to infection in humans and animal models. In AA Mahmoud, Schistosomiasis, Imperial College Press, London, p. 133-212.

4. Chitsulo, L., LoVerde, P. and Engels, D. (2004): Schistosomiasis. Nat. Rev. Microbiol., 2:12-3.

5. Nascimento, E.J.M., Leão, I.C., Pereira, V.R.A., Gomes, Y.M., Chikhlikar, P., August, T., Marques, E. and Lucena-Silva, N. (2002): Protective immunity of single and multi-antigen DNA vaccines against schistosomiasis.
Mem. Inst. Oswaldo Cruz 97: 105-109.

6. Shalaby, K.A., Yin, L., Thakur, A., Christen, L., Niles, E.G. and LoVerde, P.T. (2003): Protection against Schistosoma mansoni utilizing DNA vaccination with genes encoding $\mathrm{Cu} / \mathrm{Zn}$ cytosolic superoxide dismutase, signal peptidecontaining superoxide dismutase and glutathione peroxidase enzymes. Vaccine 22: 130-136.

7. Siddiqui, A.A., Pinkston, J.R., Quinlin, M.L., Kavikondala, V., Rewers-Felkins, K.A, Phillips, T. and Pompa, J. (2005): Characterization of protective immunity induced against Schistosoma mansoni via DNA priming with the large subunit of calpain (Sm-p80) in the presence of genetic adjuvants. Parasite 12: 3-8.

8. Fonseca, C.T., Pacifico, L.G., Barsante, M.M., Rassi, T., Cassal, G.D. and Oliveira, S.C. (2006): Co-administration of plasmid expressing IL-12 with 14-kDa Schistosoma mansoni fatty acid-binding protein cDNA alters immune response profiles and fails to enhance protection induced by Sm14 DNA vaccine alone. Microbe's Infect., Jul 24: [Epub ahead of print].

9. Zhu, Y., Si, J., Harn, D.A., Xu, M., Ren, J., Yu, C., Liang, Y., Yin, X., He, W. and Cao, G. (2006): Schistosoma japonicum triose-phosphate isomerase plasmid DNA vaccine protects pigs against challenge infection. Parasitology 132: 67-71. 
10. Abath, F.G.C., Xavier, E.M., Allen, R., Gomes, Y.M., Lucena-Silva, N., Baliza, M. and Simpson, A.J.G. (2000): Characterization of Sm13, a tegumental antigen of Schistosoma mansoni. Parasitol. Res., 86: 745-752.

11. Hochschild, A. and Dove, S.L. (1998): Protein-protein contacts that activate and repress prokaryotic transcription. Cell 92:597-600.

12. Pabo, C.P. and Sauer, R.T. (1992): Transcriptional factors: Structural, families and principles of DNA recognition. Ann. Rev.Biochem., 61:1053-1095.

13. Gaetano, M., Luigi, R., Sabrina, E., Ilaria, B., Laura, Z., Emilia, M., Pedone, Benedetto, DiBlasio, Carla, I., Paolo, V. Pedone and Roberto, F. (2007): The prokaryotic Cys2His2 zinc finger adopts a novel as revealed by the NMR structure of Agrobacterium tumefaciens Ros DNA-binding domain. Proc.Natl.Acad.Sci., USA 104: 17341-17346.

14. Burley, S.K. and Roeder, R.G. (1996): Biochemistry and structural biology of transcriptional factor IID (TFDII). Ann.Rev.Biochem., 65:769-799.

15. Paulo, R. E., Analina, F. V., Carlos, E. C., Glória,R. F., Marcos, A. d. and Frederico, G. C. A. (2001): Cloning and Characterization of SmZF1, a Gene Encoding a Schistosoma mansoni Zinc Finger Protein. Mem. Inst. Oswaldo
Cruz vol.96 suppl. Rio de Janeiro Sept.

16. Lazdins, J. K., Stein, M., David, J.B. and Sher, A. (1982): Schistosoma mansoni: rapid isolation and purification of schistosomula of different developmental stages by centrifugation on discontinuous density gradients of percoll. Exp. Parasitol., 53: $39-44$.

17. Basch, P . F. (1981) : Cultivation of Schistosama mansoni in vitro. I. Establishment of cultures from cercariae and development until pairing. J. Parasitol., 67:179-185.

18. Huynh, T. V., Young, R. A. and Davis, $R$.W. (1985): Construction and screening cDNA libraries in lambda gt10 and lambda gtll in DNA cloning: A practical Approach (Glover, D. M. ed.), vol. 1, pp. 49 - 78. IRL Press. Washington, D.C.

19. Maniatis, T., Fritsch, E.F. and Sambrook, J. (1982): Molecular cloning. A laboratory manual. Cold Spring Harbor Laboratory, Cold Spring Harbor. NY.

20. Hanahan, D. (1983): Studies on Transformation of Escherichia Coli with plasmids. J. Mol. Biol . , 166: 557- 80.

21. Saiki, R. K., Gelford, D. H., Stoffel, S., Scharf, S. J., Higushi, R., Harn, G. T., Mullis, K. B. and Erlich, H. A. (1988): Primer -directed enzymatic amplification of DNA with thermostable DNA polymerase. Science 239: 487-91.

22. Sambrook, J., Fritsch, E.F. and Maniatis, T. (1989): "Molecular Cloning: A laboratory Manual, 
"2nd. ed. Cold Spring Harbor. Laboratory Press., New York.

23. Sanger, F., Nichlen, S. and Coulson, A.R. (1977): DNA sequencing with chain terminating inhibitors. Proc.Natl.Acad.Sci.,USA 74:5493-67.

24. Loukas, A. Bethony J.M. (2008): New drugs for an ancient parasite. Nat. Med., 14:365-367

25. Bergquist, R., Al-Sherbiny, M., Barakat, R. and Olds, $R$. (2002): Blueprint for schistosomiasis vaccine development. Acta Trop., 82: 183-192.

26. Curwen, R.S., Ashton, P.D., Johnston, D.A. and Wilson, R.A. (2004): The Schistosoma mansoni soluble proteome: a comparison across four life-cycle stages. Mol. Biochem. Parasitol., 138: 57-66.

27. Min, W., Xin-Yuan, Y., XianPing, L., Dong-Ming. Z., McReynolds, L. and XianFang, Z. ( 2005): Phage displaying peptides mimic schistosoma antigenic epitopes selected by rat natural antibodies and protective immunity induced by their immunization in mice. World J. Gastroenterol., 11(19):2960-2966.

28. Dillon, G.P., Feltwell, T., Skelton, J.P., Ashton, P.D., Coulson, P.S., Quail, M. A., Nikolaidou, Katsaridou, N., Wilson, R.A. and Ivens, A.C. (2006): Microarray analysis identifies genes preferentially expressed in the lung schistosomulum of Schistosoma mansoni. Int. J. Parasitol., 36: 18.

29. Verjovski-Almeida, S., DeMarco, R., Martins, E.A., Guimaraes, P.E., Ojopi, E.P. Paquola, A.C., Piazza, J.P., Nishiyama, M.Y., Jr., Kitajima, J.P., Adamson, R.E., Ashton, P.D., Bonaldo,M.F., Coulson, P.S., Dillon, G.P., Farias, L.P., Gregorio, S.P., Ho, P.L., Leite, R. A., Malaquias, L.C., Marques, R.C., Miyasato, P.A., Nascimento, A.L., Ohlweiler, F.P., Reis, E.M., Ribeiro, M.A., Sa, R.G., Stukart, G.C., Soares, M.B., Gargioni, C., Kawano, T., Rodrigues, V., Madeira, A.M., Wilson, R.A., Menck, C.F., Setubal, J.C., Leite, L.C. and Dias-Neto, E. ( $2003 \quad$ ): Transcriptome analysis of the acoelomate human parasite Schistosoma mansoni. Nat. Genet., 35: 148-157

30. Han, Z.G., Brindley, P.J., Wang, S.Y. and Chen, Z. (2009): Schistosome Genetics: New Perspectives on Schistosome Biology and HostParasite Interaction. Annu Rev Genomics Hum Genet.

31. Ojopi, E.P., Oliveira, P.S., Nunes, D.N., Paquola, A., DeMarco, R., Gregorio, S.P., Aires, K.A., Menck, C.F., Leite, L. C., Verjovski-Almeida, S. and Dias-Neto, E. (2007): A quantitative view of the transcriptome of Schistosoma mansoni adult-worms using SAGE. BMC Genomics. 2007;8:186.

32. Marcela, G. D., Carlos, E. Calzavara-Silva, Diego, S. 
D'Astolfo, Fernanda, C. Cardoso, Matheus, A. Rajão, Marina, M. Mourão, Elisandra, G., Sérgio, C. O., Andréa, M. M., Carlos, R. M., Sérgio, D. J. P., Gregory, T. K. and Glória, R. F. (2009): Molecular Characterization of the Schistosoma mansoni Zinc Finger Protein SmZF1 as a Transcription Factor. PLoS Negl. Trop. Dis., November; 3(11): e547.

33. Yuko, O., Kazunori, I., Hiroaki, M., Takafumi, M., Michio, $\mathbf{H}$. and Koji, S. (2008): The simple and rapid detection of specific PCR products from bacterial genomes using $\mathrm{Zn}$ finger proteins. Nucleic Acids Res., 36 (11) e68.

34. Gamsjaeger, R., Liew, C.K., Loughlin, F.E., Crossley, M., Mackay,T.P. and Crossley, M. (2007): Sticky finger: zincfingers as protein-recognition motifs. Trends Biochem. Sci., 32(2): 63-70.

35. Klug, A. and Schwabe, J.W. (1997): Protein motifs 5.zinc fingers. FABES J., 9(8): 597-604.

36. Hokke, C.H., Fitzpatrick, J.M. and Hoffmann, K.F. (2007): Integrating transcriptome, proteome and glycome analyses of Schistosoma biology. Trends Parasitol., 23:165-174

37. Eleuterio, d. P.R., Valadao, A.F., Calzavara-Silva, C.E., Franco, G.R., de Morais, M.A.
Jr. and Abath, F.G.(2001): Cloning and characterization of SmZF1, a gene encoding a Schistosoma mansoni zinc finger protein. Mem. Inst. Oswaldo Cruz. 96(Suppl):123-130.

38. Lee, D.K., Seal, W. and Kim, J.C. (2003): Custom DNAbinding proteins and artificial transcription factors. Current Tropics in medicinal Chemistry 3: 339-353.

39. Dreier, B., Fuller, R.P., Segal, D.J., Lund, C.V., Blancafort, P., Huber, A., Kokasch, B. and Barbas, C.F. (2005): $3^{\text {rd }}$ : Development of zinc finger domains for recognition of the 5/$\mathrm{CNN}-3 /$ family DNA sequences and their use in the construction of artificial transcription factors. J. Biol. Chem., 280: 3558835597.

40. Mandell, S.G. and Barbas, C.F. (2006): III Zinc finger tools, custom DNA binding domains for transcription factors and nucleases. Nucleic Acids Res., 34: W516-W523.

41. Papworth, M., Kolasinska, P. and Minczuk, M. (2006): Designer zinc finger proteins and their applications. Gene 366: 2738.

42. Varshavsky, A. (2007): From the cover: targeting the absence, homozygous DNA deletions as immutable signposts for cancer therapy. Proc. Natl. Acad. Sci., USA 104: 14935-14940. 


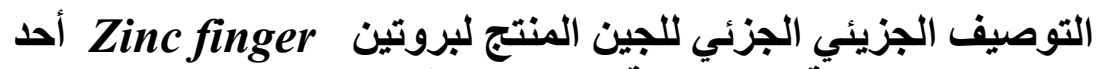

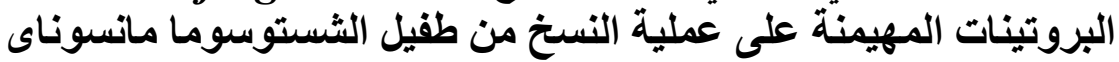

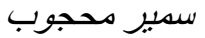 \\ قسم الكيمياء الحيوية_ كلية الطب-جامعة المنيا
}

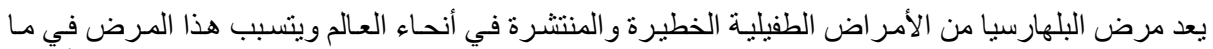

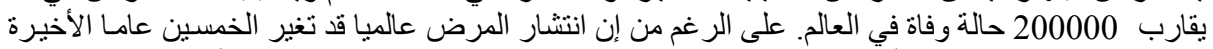

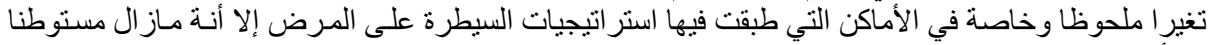

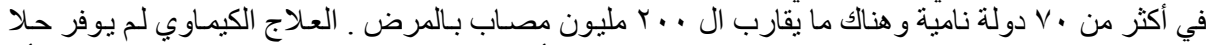

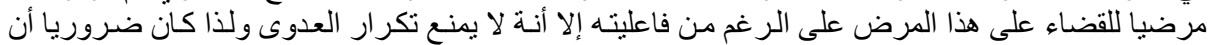

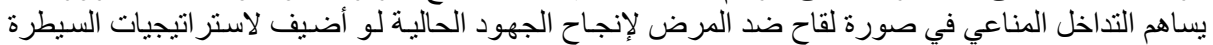

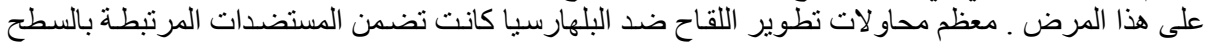

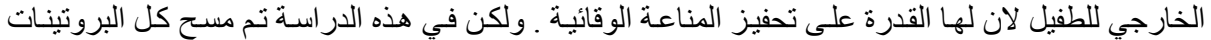

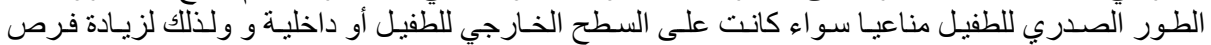

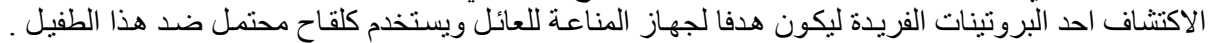

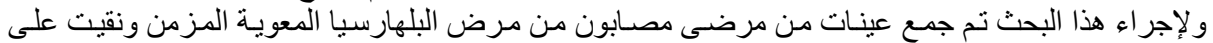

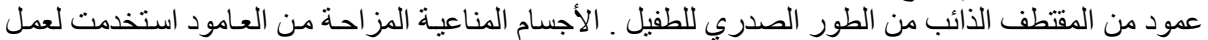

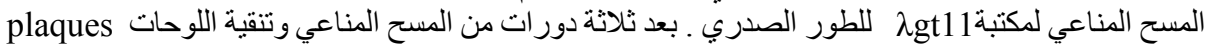

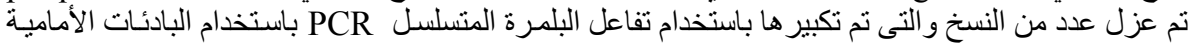

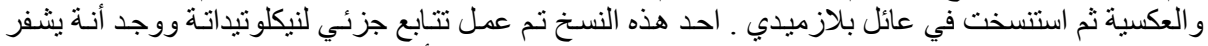

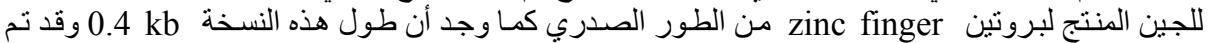

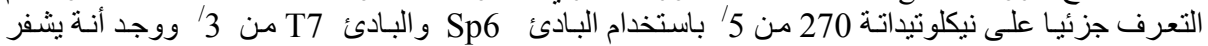

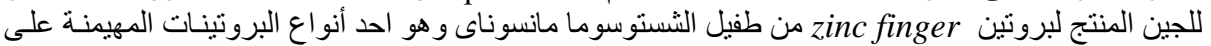

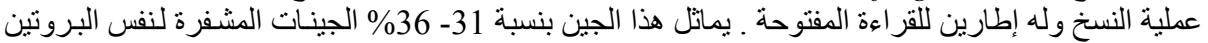

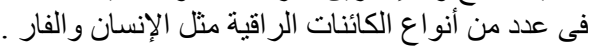

